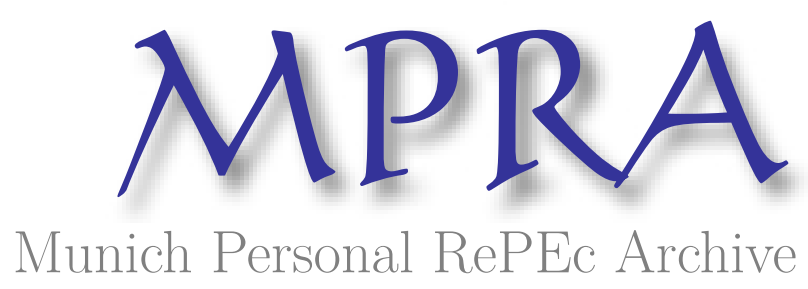

\title{
Governance of Innovation in the Different Countries of the World
}

Manuel, Eduardo

9 October 2006

Online at https://mpra.ub.uni-muenchen.de/3037/

MPRA Paper No. 3037, posted 04 May 2007 UTC 


\title{
GOVERNANCE OF INNOVATION IN THE DIFFERENT COUNTRIES OF THE WORLD
}

\author{
EDUARDO G. MANUEL \\ B.A in Economics and MSc in Management of Enterprises \\ at University Autonoma of Lisbon (UAL), Portugal \\ Economist, Investigator and Editor \\ E-mail address: edu.manuel@economista.com
}

\begin{abstract}
This paper has as objective to approach the "Governance of Innovation in the different countries of the World", using information from World Economic Forum.

The improve of cooperation between richest and poorest countries and between the poorest countries (between South Africa and Zambia, for example) is necessary to extract lessons and so to solve problems at level of what is necessary, what is missing and what is falling at the progress of nations more poor in knowledge that is cause of low level of innovation and economic development.
\end{abstract}

Keywords: Governance, Innovation, Governance of Innovation

JEL Codes: M29, O31, O38, O39

Working Paper Series 


\section{INTRODUCTION}

\section{What is innovation?}

An important distinction is normally made between invention and innovation (Fagerberg, Mowery, et al, 2005). According to these authors, Invention is the first occurrence of an idea for a new product or process, while innovation is the first attempt to carry it out into practice. Sometimes, invention and innovation are closely linked, to the extent that is hard to distinguish one from another (biotechnology for instance). While inventions may be carried out anywhere, for example in universities, innovations occur mostly in firms, though they may also occur in other types of organizations, such as public hospitals, and to be able to turn an invention into an innovation, a firm normally needs to combine several different types of knowledge, capabilities, skills and resources.

Innovation is a powerful explanatory factor behind differences in performance between firms, regions, and countries. So, firms that succeed in innovation prosper at the expense of their less able competitors, and innovative countries and regions have higher productivity and income than less innovative ones.

This paper has as objective to approach the "Governance of Innovation in the different countries of the World, using information from World Economic Forum.

\section{GOVERNANCE OF INNOVATION. DEFINITION}

Governance consist on form how are organised activities of governs the politics agents, administrative, and social (OCDE, 2001).

Governance means the act of governing, the planning, influencing, and conducting of the policy and affair of an organization or country.

Governance of Innovation means to supplier what is missing, to manage what exist, and what is necessary as well as to improve what is falling on the technological progress. 


\section{What is happening to G-8 Countries?}

Japan is the member state of G-8 that is governing better the innovation, because it appears with the best classification at level of innovation, it is in $1^{\text {st }}$ position on World ranking, having the best ranking compared with 125 countries showed in this study for 2006-2007 (see annex - table 1) (cf. World Economic Forum, 2006).

Following Japan it is USA in $2^{\text {nd }}$ and Germany that is in $5^{\text {th }}$. Russian Federation $\left(59^{\text {th }}\right)$ and Italy $\left(43^{\text {rd }}\right)$ are the countries of G- 8 with poorest position on innovation ranking.

\section{What is happening in the World?}

According to World Economic Forum (2006), Japan is the country that registered the best position on world ranking at level of innovation, it is in $1^{\text {st }}$ position, being the country of the world that is governing better the innovation (see annex - table 1).

In the $2^{\text {nd }}$ position appear the United States, and in $3^{\text {rd }}$ we have Switzerland. In the last position, we have Timor-Leste $\left(124^{\text {th }}\right)$, Paraguay $\left(123^{\text {rd }}\right)$ and Chad $\left(122^{\text {nd }}\right)$.

The poorest positions at this level are the African countries such as Angola (12 $\left.{ }^{\text {st }}\right)$, Burundi $\left(119^{\text {th }}\right)$, Chad $\left(122^{\text {nd }}\right)$, Ethiopia $\left(114^{\text {th }}\right)$, Lesotho $\left(117^{\text {th }}\right)$, and others like TimorLeste (as we had already seemed).

According to graphic 1, we can see that the best position on world ranking at level of innovation are the countries with high level of education and training, for example, if we see the table 1 (see annex), its easy to understand that United States is in $2^{\text {nd }}$ position at level of innovation and it is in $5^{\text {th }}$ position at level of higher education and training, the same it happens to Finland that it is in $4^{\text {th }}$ at level of innovation and has the best position in higher education and training ( $1^{\text {st }}$ position). Whereas countries like Zambia that is in $117^{\text {th }}$ at level of higher education and training and it is in 118th in innovation, the same it happens to Mauritania, that is in $121^{\text {st }}$ at level of higher education and training and it is in $108^{\text {th }}$ position at level of innovation. 
GRAPHIC 1 - Higher Education and Training vs. Innovation

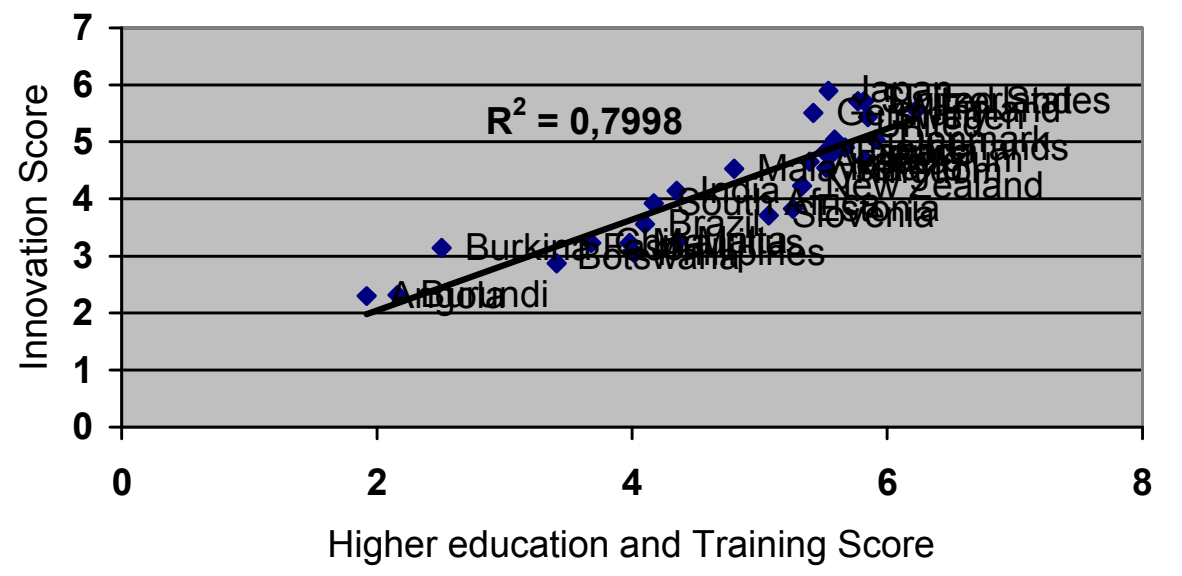

India registered better position than China, having India registered the $26^{\text {th }}$ position and China the $46^{\text {th }}$. And it is important to refer that India has more higher education and training level than China, and if we see the table 1 (see annex), we can verify that China is in $77^{\text {th }}$ position and India is in $49^{\text {th }}$ at this level.

\section{CONCLUSIONS}

We saw the state of innovation of the different countries of the World and to understand so which countries are governing and managing better/poor the innovation in era globalization.

We concluded that the richest countries are continuing to register the best position according to information edited by World Economic Forum (2006), and the gap between North and South is visible at level of governance and management of innovation.

The improve of cooperation between richest and poorest countries and between the poorest countries (between South Africa and Zambia, for example) is necessary to extract lessons and so to solve problems at level of what is necessary, what is missing and what is falling at the progress of nations more poor in knowledge that is cause of low level of innovation and economic development. 


\section{REFERENCES}

Facerberg J, Mowery DC, et al. 2005. The Oxford Handbook of Innovation. First Published. Oxford University Press: Oxford and New York

Organization for Economic Co-operation and Development. 2001. A Governância no Século XXI, Gabinete de Estudos e Prospectiva Económica (GEPE), Ministério da Economia, Lisboa

World Economic Forum. 2006. The Global Competitiveness Report 2006-2007.

Michael E. Porter, Klaus Schwab, Xavier Sala-i-Martin and Augusto Lopez-Claros (eds). Palgrave Macmillan: New York 
ANNEXES 
TABLE 1 - Higher education and Training and Innovation in the different Countries of the World

\begin{tabular}{|c|c|c|c|c|}
\hline \multirow[b]{2}{*}{ Country } & \multicolumn{2}{|c|}{$\begin{array}{c}\text { Higher education and } \\
\text { Training }\end{array}$} & \multicolumn{2}{|c|}{ Innovation } \\
\hline & Rank & Score & Rank & Score \\
\hline Algeria & 84 & 3.46 & 76 & 3.09 \\
\hline Angola & 125 & 1.92 & 121 & 2.30 \\
\hline Argentina & 39 & 4.51 & 83 & 3.03 \\
\hline Austria & 19 & 5.39 & 17 & 4.65 \\
\hline Belgium & 4 & 5.83 & 16 & 4.68 \\
\hline Benin & 101 & 2.96 & 90 & 2.87 \\
\hline Botswana & 87 & 3.41 & 91 & 2.87 \\
\hline Brazil & 60 & 4.10 & 38 & 3.56 \\
\hline Burkina Faso & 116 & 2.51 & 69 & 3.14 \\
\hline Burundi & 123 & 2.16 & 119 & 2.32 \\
\hline Cambodia & 110 & 2.63 & 98 & 2.72 \\
\hline Cameroon & 103 & 2.85 & 97 & 2.73 \\
\hline Canada & 17 & 5.51 & 13 & 4.82 \\
\hline Chad & 124 & 1.99 & 122 & 2.26 \\
\hline Chile & 40 & 4.48 & 39 & 3.56 \\
\hline China & 77 & 3.68 & 46 & 3.44 \\
\hline Cyprus & 41 & 4.48 & 55 & 3.30 \\
\hline Czech Republic & 27 & 5.04 & 28 & 3.98 \\
\hline Denmark & 2 & 5.91 & 10 & 5.04 \\
\hline Egypt & 75 & 3.73 & 82 & 3.04 \\
\hline Estonia & 23 & 5.26 & 30 & 3.83 \\
\hline Ethiopia & 120 & 2.39 & 114 & 2.50 \\
\hline Finland & 1 & 6.23 & 4 & 5.56 \\
\hline France & 12 & 5.57 & 14 & 4.80 \\
\hline Gambia & 106 & 2.81 & 115 & 2.48 \\
\hline Germany & 18 & 5.42 & 5 & 5.51 \\
\hline Greece & 34 & 4.78 & 47 & 3.43 \\
\hline Hungary & 30 & 4.93 & 31 & 3.82 \\
\hline India & 49 & 4.35 & 26 & 4.14 \\
\hline Indonesia & 53 & 4.25 & 37 & 3.60 \\
\hline Ireland & 16 & 5.52 & 20 & 4.54 \\
\hline Italy & 35 & 4.77 & 43 & 3.50 \\
\hline Japan & 15 & 5.54 & 1 & 5.90 \\
\hline Kenya & 88 & 3.41 & 48 & 3.42 \\
\hline Latvia & 28 & 5.01 & 66 & 3.19 \\
\hline Lesotho & 115 & 2.52 & 117 & 2.37 \\
\hline Lithuania & 29 & 4.97 & 50 & 3.35 \\
\hline Luxembourg & 45 & 4.42 & 23 & 4.36 \\
\hline Madagascar & 113 & 2.55 & 77 & 3.07 \\
\hline Malawi & 119 & 2.46 & 103 & 2.70 \\
\hline Malaysia & 32 & 4.80 & 21 & 4.53 \\
\hline
\end{tabular}




\begin{tabular}{|l|c|c|c|c|}
\hline Mali & 118 & 2.48 & 80 & 3.04 \\
\hline Malta & 47 & 4.36 & 62 & 3.26 \\
\hline Mauritania & 121 & 2.33 & 108 & 2.60 \\
\hline Mauritius & 68 & 3.98 & 65 & 3.23 \\
\hline Mexico & 71 & 3.88 & 58 & 3.29 \\
\hline Mozambique & 122 & 2.30 & 110 & 2.58 \\
\hline Namibia & 105 & 2.82 & 88 & 2.91 \\
\hline Netherlands & 8 & 5.67 & 11 & 4.90 \\
\hline New Zealand & 22 & 5.33 & 25 & 4.23 \\
\hline Nigeria & 100 & 3.04 & 52 & 3.33 \\
\hline Paraguay & 102 & 2.93 & 123 & 2.20 \\
\hline Philipines & 63 & 4.02 & 79 & 3.05 \\
\hline Poland & 33 & 4.79 & 44 & 3.47 \\
\hline Portugal & 37 & 4.63 & 32 & 3.81 \\
\hline Russian Federation & 43 & 4.44 & 59 & 3.28 \\
\hline Singapore & 10 & 5.59 & 9 & 5.04 \\
\hline Slovak Republic & 38 & 4.52 & 42 & 3.51 \\
\hline Slovenia & 26 & 5.07 & 34 & 3.71 \\
\hline South Africa & 56 & 4.17 & 29 & 3.92 \\
\hline Spain & 31 & 4.86 & 35 & 3.68 \\
\hline Sweden & 3 & 5.85 & 6 & 5.44 \\
\hline Switzerland & 6 & 5.77 & 3 & 5.72 \\
\hline Thailand & 42 & 4.44 & 33 & 3.74 \\
\hline Timor-Leste & 111 & 2.62 & 124 & 2.14 \\
\hline Tunisia & 36 & 4.72 & 27 & 4.05 \\
\hline Uganda & 107 & 2.78 & 72 & 3.11 \\
\hline United Kingdom & 11 & 5.57 & 12 & 4.89 \\
\hline United States & 5 & 5.82 & 2 & 5.72 \\
\hline Uruguay & 55 & 4.19 & 74 & 3.10 \\
\hline Vietnam & 90 & 3.39 & 75 & 3.10 \\
\hline Zambia & 117 & 2.48 & 118 & 2.35 \\
\hline Zimbabwe & 96 & 3.10 & 93 & 2.86 \\
\hline & & & & \\
\hline & & & 3 & \\
\hline
\end{tabular}

Source: World Economic Forum. 2006 